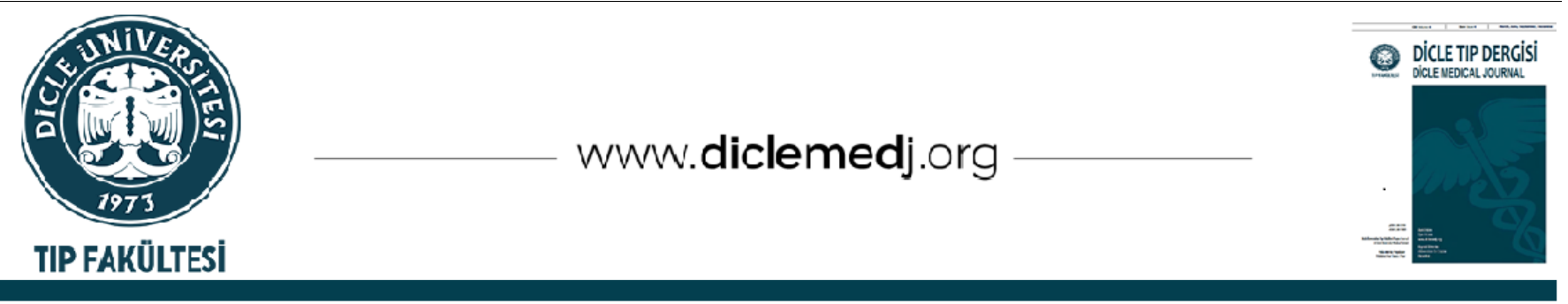

Original Article / Özgün Araştırma

\title{
The Effects of Ethyl Pyruvate on Behavioral and Biochemical Parameters in Immobilization Stress-Induced Mice
}

\author{
Mihrab Abul ${ }^{\text {i }}$, Hasan Akkoc ${ }^{\text {iD }}$, Emre Uyar ${ }^{\text {iD }}$ 2, Suleyman Donmezdil iD 3 \\ 1 Department of Pharmacology, Faculty of Medicine, Dicle University, Diyarbakir, Turkey \\ 2 Department of Pharmacology, Faculty of Pharmacy, Inonu University, Malatya, Turkey \\ 3 Department of Psychiatry, Gazi Yasargil Training and Research Hospital, University of Health Sciences, Diyarbakir, Turkey
}

Received: 18.01.2021; Revised: 30.07.2021; Accepted: 02.08.2021

\begin{abstract}
Objective: Ethyl pyruvate (EP) is a molecule with antioxidant, anti-inflammatory, and anti-apoptotic features. The present study investigates EP's effects on behavioral and biochemical alterations induced by immobilization (IM) stress.

Methods: In this outcome, 45 male BALB/c mice were separated into five groups [CONT (control), IM, IM+EP, EP, IM+F (fluoxetine)]. IM applied groups had 6 hours of immobilization stress procedure a day for a week. EP (50 mg/day) and fluoxetine ( $5 \mathrm{mg} /$ day) were applied to the mice intraperitoneally. After the stress induction protocol, passive avoidance, open field (OF), and forced swimming tests (FST) were executed. After behavioral tests, brain tissues were obtained for biochemical investigations.
\end{abstract}

Results: Immobilization application increased immobility times in the FST and decreased the total distance moved and the center time in the OF test. Immobile times were reduced with fluoxetine and EP applied groups compared with the IM group due to decreased learned helplessness. The IM group had decreased brain-derived neurotrophic factor (BDNF), superoxide dismutase, and glutathione peroxidase levels, which were increased with EP applications.

Conclusion: These results show that EP generates antidepressant-like effects with decreasing oxidation and increasing BDNF levels.

Keywords: Ethyl pyruvate, forced swimming test, glutathione peroxidase (GPx), brain-derived neurotrophic factor (BDNF), antidepressant effects

DOI: 10.5798/dicletip.988063

Correspondence / Yazışma Adresi: Emre Uyar, Inonu University, Faculty of Pharmacy, Pharmacology Department, Malatya, Turkey, Postal Code: 44210 e-mail: eczemreuyar@hotmail.com 


\section{İmmobilizasyon stresine maruz bırakılan farelerde etil pirüvatın davranışsal ve biyokimyasal parametreler üzerine etkileri}

$\ddot{0} \mathbf{z}$

Amaç: Etil Pirüvat (EP), antioksidan, antiinflamatuvar ve antiapoptotik etkileri bilinen bir moleküldür. Bu çalışma ile, EP'ın, immobilizasyon stres (IM) ile indüklenen biyokimyasal ve davranışsal parametre değişiklikleri üzerine etkilerini araştırmak amaçlanmıştır.

Yöntemler: Bu amaçla, 45 BALB/c fare, 5 gruba ayrıldı [CONT, IM, IM+EP, EP, IM+F (fluoksetin)]. IM uygulanan gruplar 1 hafta boyunca günde 6 saat immobilizasyon stresine maruz birakıldı. EP (50 mg/g) ve fluoksetin (5 mg/g) deneklere intraperitoneal olarak enjekte edildi. Stres indüksiyonu sürecinin sonunda, farelere zorunlu yüzme testi (ZYT), açık alan (AA) testi ve pasif sakınma (PS) testleri uygulandı. Davranış deneyleri tamamlanan denekler, servikal dekapitasyon suretiyle sakrifiye edildi ve biyokimyasal incelemeler için beyin dokuları izole edildi.

Bulgular: IM grubunda, ZYT 'nde hareketsiz zamanda artış, AA testinde, toplam katedilen mesafe ve merkezde geçirilen sürede azalma gözlemlendi. Öğrenilmiş çaresizlikte bir azalma ile bağlantılı olarak, ZYT 'nde hareketsiz zamanın IM+EP ve IM+F gruplarında, IM grubuna kıyasla azaldığı gözlemlendi. IM grubunda azalan beyin-kaynaklı nörotrofik faktör (BDNF), glutatyon peroksidaz ve süperoksit dismutaz seviyeleri, IM+EP grubunda, IM grubuna kıyasla, anlamlı artış gösterdi.

Sonuç: Bu veriler, EP' ın, oksidasyonu azaltmak ve BDNF seviyelerini artırmak suretiyle antidepresan-benzeri etkiler gösterdiğini ortaya koymaktadır.

Anahtar kelimeler: Etil pirüvat, zorunlu yüzme testi, beyin-kaynaklı nörotrofik faktör (BDNF), antidepresan, glutatyon peroksidaz (GPx) süperoksit dismutaz (SOD).

\section{INTRODUCTION}

Stress occurs with changes in physiologic, psychological, and environmental factors and affects psychologic and biochemical homeostasis ${ }^{1}$. Chronic stress is shown to produce increments in the possibility of developing many physiological and psychological diseases, including increased depression-like behavior and anxiety levels and learning and memory disruptions ${ }^{2,3}$.

The pathophysiology of stress is still not entirely known. Some of the causes of stress are monoaminergic transmitter deficiency, hypoactivity of the hypothalamic-pituitaryadrenal (HPA) axis, and inflammation. Furthermore, neurochemical, as well as hormonal alterations, are shown to be related to stress $^{2}$. Studies revealed that subchronic stress results in increased lipid peroxidation and nitrite levels and reduced glutathione levels, which are stated to be related to increased stress exposure ${ }^{5}$. Increased stress hormone production due to the HPA axis's hyperactivity causes reactive oxygen species (ROS), which results in increased oxidation. Primarily cortisol, which increases blood pressure and heart rate, increases the outflow of oxygen to target organs, especially to the brain. Increased oxygen levels in the tissues produce degenerative effects in the cells. Cortisol disrupts the electron transport chain and causes a leak of electrons by breaking down the mitochondrial enzymes. These events cause increased free-electron release, which interrupts cellular mechanisms ${ }^{6}$.

Pyruvate (2-oxopropanoic acid) is a side product of adenosine triphosphate (ATP) metabolism ${ }^{7}$. Pyruvate acts as a potent antioxidant and a neuroprotective agent with reducing free oxygen radicals and hydrogen peroxide (H2O2) levels due to the alpha-keto carbonyl group on its structure. As a result, the production of pyruvate with glycolysis reduces oxidative stress to a minimal state ${ }^{7}$. Pyruvate is not a stabilized molecule, and when absorbed, it 
is metabolized to parapyruvate. Later, it dimerizes to pyruvate hydrate, which acts as a toxic inhibitor of a crucial step in the mitochondrial tricarboxylic acid (TCA) cycle? To prevent this, in calcium and potassiumcontaining alkaline solution, ethyl pyruvate (EP), a steady pyruvate derivative, was synthesized $^{8}$. EP is electrically neutral, and penetrates the cells rapidly and doesn't need the transporters necessary for pyruvate to enter the cell ${ }^{7,8}$.

Studies stated that EP is a neuroprotective agent, and this effect of EP is linked with its antioxidant, anti-apoptotic, and antiinflammatory effects ${ }^{4,8}$. The antioxidant effects of EP are claimed to be related to its ROS reducing effects and easing of breaking down H2O2 in the PC12 cells, which are related to dopaminergic transmission ${ }^{8}$.

This study aimed to investigate behavioral and biochemical alterations caused by immobilization stress and the effects of EP in stress-induced changes in mice.

\section{METHODS}

\section{Animals}

The present experiment was carried out at Dicle University Psychopharmacology Laboratory. In this research, male BALB/c mice (35-45 g, 8-12 weeks) were used. The mice were obtained from Dicle University Animal Colony Facility, kept and maintained at normal laboratory conditions, $23 \pm 2^{\circ} \mathrm{C}, 60 \%$ humidity, until the end of the experimental procedure. The mice accessed the food pellets and tap water ad libitum. This study's procedures complied ethically with the local Ethics Committee approval (DUHADEK, Approval date: 30.05.2017, Number: 2017-06) and following The European Community Council Directive 86.

Groups and Drug Application Protocol

$\mathrm{EP}(50 \mathrm{mg} / \mathrm{kg})$ and fluoxetine $(5 \mathrm{mg} / \mathrm{kg})$ or saline injections, and the immobilization protocol continued for seven days. Five groups were created for the experiment (n: 7-9). The control group (CONT) received daily intraperitoneal (ip) $0.9 \%$ saline injections. The immobilization group (IM) underwent daily immobilization and had saline injections. The immobilization+ethyl pyruvate (IM+EP) group underwent daily immobilization protocol and had EP injections. The EP group had daily EP injections. The immobilization+fluoxetine $(\mathrm{IM}+\mathrm{F})$ group had daily immobilization and fluoxetine injections. Mice were immobilized in height-adjustable cages (diameter: $4 \mathrm{~cm}, 6$ hours/day) for seven consecutive days to induce stress.

Drugs or saline $(10 \mathrm{ml} / \mathrm{kg})$ were administered intraperitoneally 30 mins before the beginning of the immobilization procedure. The drugs used in the experiment were obtained from Sigma-Aldrich (St. Louis, MO, USA). On the 8th experimental day, the mice underwent behavioral tests. They were then sacrificed, and the hippocampi and prefrontal cortex tissues were obtained. The tissues were maintained at $80{ }^{\circ} \mathrm{C}$ till biochemical investigations.

\section{Open Field (OF) Test}

The locomotion and willingness to explore of the mice were assessed using an OF test. Prut and Belzung first reported this test for the evaluation of anxiety-like behavior'. Each mouse was put in the OF test arena center $(40 \times 40 \times 20 \mathrm{~cm})$, and the locomotor activity was videotaped for 5 mins with a camera put above. The mice's movements and behavior were examined with the video tracking program EthoVision XT11 (Netherlands). Mice's mean velocity and the total distance moved was calculated.

\section{Forced Swimming Test (FST)}

The FST was conducted with a plexiglass cylinder (h: $50 \mathrm{~cm}, \mathrm{~d}: 20 \mathrm{~cm}$ ), and the heat of the water was kept at $24-26^{\circ} \mathrm{C}$ to evade extra stress throughout the test period ${ }^{10}$. Every mouse was 
individually placed on the water and let freely swim 6 mins with no escape possibility. The tests were videotaped, and the videos were analyzed using Ethovision XT 11.0. Total immobile times in the last 4 mins of the test were measured for each mouse and considered as the index of depression.

\section{Passive Avoidance (PA) Test}

The PA test apparatus (MAY PA1014M, Ankara, Turkey) comprises two chambers $(11 \times 12 \times 20$ cm) connected with a remote-controlled automated door. The first chamber had whitecolored walls and was illumined with 2000 lux light, while the opposite chamber had blackcolored walls with no light. The PA test apparatus had an electrifiable grid floor. The tests were conducted in two days. On the acquisition trial (1st day), each mouse was placed in the illumined chamber, and after 30 secs, the door connecting the two chambers was automatically opened. The time passed for the mice to enter the dark chamber was calculated (step-through latencies) and recorded. After entering the dark chamber, the mice had an electric shock $(0.75 \mathrm{~mA})$ and were kept there for 15 secs. The mice were excluded from the experiment if not passed to the dark chamber for 300 secs. A day after the first-day test, a retention trial was conducted. In this trial, the mice were put in the light compartment once again, and the same procedure was applied with no electric shock given. The mice's step-through latencies were regarded as emotional learning and memory index. After every experiment, the grid floor was cleaned with alcohol (20\%) and water, not to affect the following mice's behavior with the olfactory cues ${ }^{11}$.

\section{Biochemical Analysis}

The brain tissues were homogenized in ice-cold PBS (phosphate-buffered saline, 0.01M, PH: 7.4). The collected homogenates were centrifuged for 5 mins $(5000 \mathrm{~g})$, and supernatants were obtained. Nerve growth factor (NGF), brain-derived neurotrophic factor (BDNF), glutathione peroxidase (GPx), and superoxide dismutase (SOD) levels in the samples were examined with an auto enzymelinked immunosorbent assay (ELISA) plate analyzer (Robonik, Thane, India) and conventionally produced kits (Elabscience Biotechnology, China) were used. The BDNF, NGF, GPx, and SOD levels were shown as ng.g-1 tissue.

\section{Statistical Analysis}

The data were examined with SPSS 24.0 (Chicago, USA) and presented as the mean \pm standard deviations. A Kruskal-Wallis and Man Whitney-U tests were used, and the p-values under 0.05 were regarded as significant.

\section{RESULTS}

\section{Open Field Test}

The OF test results were shown in table 1 . In the IM, IM+EP, and EP groups, the total distance moved was significantly reduced compared to the CONT group $(\mathrm{p}<0.01, \mathrm{p}<0.05, \mathrm{p}<0.01$, respectively). The velocity of the mice was reduced in the EP group compared with the IM and CONT groups $(\mathrm{p}<0.05, \mathrm{p}<0.01)$. Time spent in the center was reduced in the IM, IM+EP and EP groups, compared with the CONT group $(\mathrm{p}<0.05$, $\mathrm{p}<0.01, \mathrm{p}<0.01$, respectively).

Table I: Open field test results of the subjects

\begin{tabular}{|c|c|c|}
\hline Parameters & Distance* $(\mathrm{cm})$ & $\begin{array}{l}\text { Velocity* (cm } \\
\left.\mathrm{sec}^{-1}\right)\end{array}$ \\
\hline CONT & $1859,2 \pm 149,1$ & $5,92 \pm 0,61$ \\
\hline IM & $1457,6 \pm 211,5^{a}$ & $5,18 \pm 1,22$ \\
\hline $\mathrm{IM}+\mathrm{EP}$ & $1357,0 \pm 351,1^{b}$ & $4,61 \pm 1,38$ \\
\hline EP & $1075,1 \pm 176,5^{a, c}$ & $3,59 \pm 0,61^{a, c}$ \\
\hline $\mathrm{IM}+\mathrm{F}$ & $1523,7 \pm 266,2$ & $5,10 \pm 0,87$ \\
\hline \multicolumn{3}{|c|}{$\begin{array}{l}\text { Each row symbolizes the mean } \pm \text { standard deviations of } 7-9 \text { mice, } \\
\text { Statistical analysis was performed using Kruskal-Wallis and Man } \\
\text { Whitney-U tests. CONT; Control, IM; Immobilization, EP; Ethyl Pyruvate, F; } \\
\text { Fluoxetine, }{ }^{*} p<0.05 \text { for Kruskal-Wallis test, ap }<0.01 \text { vs. CONT, bp }<0.05 \text { vs. } \\
\text { CONT, cp }<0.05 \text { vs. IM. }\end{array}$} \\
\hline
\end{tabular}




\section{Forced Swimming Test}

Compared to the CONT group, immobile times of the mice in the FST increased in the IM group $(\mathrm{p}<0.05$, Table 2). Immobile times of the IM+EP, $\mathrm{EP}$, and IM+F groups were reduced compared to the IM group $(\mathrm{p}<0.05$, Table 2$)$.

Table II: Forced swimming test, immobile times

\begin{tabular}{|ll|}
\hline Parameters & Immobile times* $(\mathrm{sec})$ \\
\hline IM & $97,4 \pm 23,1$ \\
IM+EP & $132,3 \pm 21,9^{\mathrm{a}}$ \\
EP & $103,4 \pm 11,1^{\mathrm{b}}$ \\
IM+F & $100,5 \pm 8,88^{\mathrm{b}}$ \\
\end{tabular}

Each row symbolizes the mean \pm standard deviations of 7-9 mice. Statistical analysis was performed using Kruskal-Wallis and Man Whitney-U tests. CONT; Control, IM; Immobilization, EP; Ethyl Pyruvate, F; Fluoxetine, ${ }^{*} p<0.05$ Kruskal-Wallis test, ap<0.05 vs. CONT, $b p<0.05$ vs. IM.

\section{Passive Avoidance Test}

The PA test results were shown in table 3. In the acquisition trial, the IM group's step-through latencies were significantly higher compared to the CONT group $(\mathrm{p}<0.05)$. In this trial, stepthrough latencies were lower in the IM+EP group compared to the IM group $(\mathrm{p}<0.05)$.

In the retention trial, the $\mathrm{IM}, \mathrm{IM}+\mathrm{EP}$, and $\mathrm{IM}+\mathrm{F}$ groups' step-through latencies were higher than the CONT group. However, only the latencies of the IM+EP group significantly differed from the CONT group $(\mathrm{p}<0.01)$.
Table III: Passive avoidance test, step-through latencies of the mice, acquisition and retention trial

\begin{tabular}{|lll|}
\hline & Acquisition trial* (sec) & Retention trial* (sec) \\
\hline CONT & $29,1 \pm 11,1$ & $135,0 \pm 71,3$ \\
IM & $64,5 \pm 37,0^{\text {a }}$ & $181,2 \pm 104,7$ \\
EP & $18,5 \pm 12,9^{c}$ & $282,5 \pm 18,9^{\mathrm{b}}$ \\
IM+F & $61,5 \pm 37,6$ & $140,2 \pm 84,5$ \\
& $44,5 \pm 38,1$ & $186,2 \pm 118,1$ \\
\hline
\end{tabular}

Each row symbolizes the mean \pm standard deviations of 7-9 mice. Statistical analysis was performed using Kruskal-Wallis and Man Whitney-U tests. CONT; Control, IM; Immobilization, EP; Ethyl Pyruvate, F; Fluoxetine, ${ }^{*} p<0.05$ Kruskal-Wallis test, ap<0.05 vs. CONT, bp<0.01 vs. CONT, $c p<0.05$ vs. IM.

\section{Biochemical Results}

Figure 1 (a-d) represents the results of the BDNF, NGF, GPX, and SOD levels on the brain tissue samples. BDNF, NGF, GPx and SOD levels were significantly lower in the IM group compared to the CONT group $(\mathrm{p}<0.01, \mathrm{p}<0.05$, $\mathrm{p}<0.01, \mathrm{p}<0.01$, respectively). BDNF, GPx, and SOD levels were significantly increased in the IM+EP group compared with the IM group ( $\mathrm{p}<0.01, \mathrm{p}<0.01, \mathrm{p}<0.05$, respectively). The increment in NGF levels was not observed significant ( $p>0.05)$. The biochemical results of the IM+EP group, compared to the IM+F group, were not statistically significant ( $>00.05)$. BDNF, NGF, and GPx levels were increased in the IM+F group compared to the IM group ( $\mathrm{p}<0.05, \mathrm{p}<0.05, \mathrm{p}<0.01$, respectively). SOD levels were slightly increased in the $\mathrm{IM}+\mathrm{F}$ group compared with the IM group but did not reach statistical significance ( $p>0.05)$. 

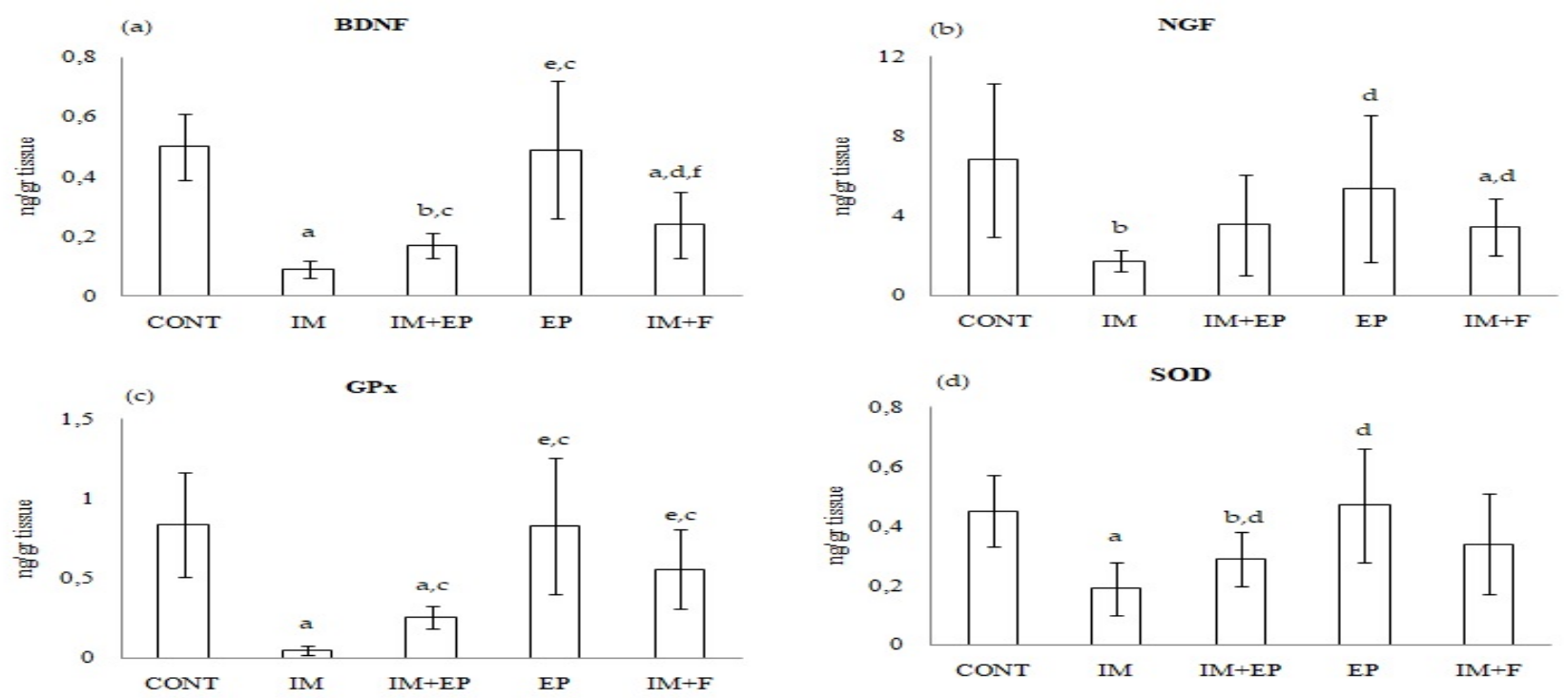

Figure I (a-d): Brain tissue of the mice, (a) BDNF, (b) NGF, (c) GPx, and (d) SOD levels. Each row symbolizes the mean \pm standard deviations of 7-9 mice. Statistical analysis was performed using Kruskal-Wallis and Man Whitney-U tests. CONT; Control, IM; Immobilization, EP; Ethyl Pyruvate, F; Fluoxetine, BDNF;

Brain-derived neurotrophic factor, NGF; Nerve growth factor, GPx; Glutathione peroxidase, SOD; Superoxide dismutase, CAT; Catalase, ap $<0.01$ vs. CONT, bp $<0.05$ vs. CONT, $c p<0.01$ vs. IM, $d p<0.05$ vs. IM, ep $<0.01$ vs. IM+EP, fp $<0.05$ vs. EP.

\section{DISCUSSION}

In the present study, the effects of EP on behavioral and biochemical parameters against induced stress were investigated in mice. An immobilization model was conducted to provoke stress in rodents. In the conducted behavioral and biochemical tests, distinct changes in the rodent behaviors, significant differences in neurotrophic factors, and antioxidant enzyme levels were observed. These results correspond to the studies that were carried out with the immobilization model to induce stress ${ }^{12}$.

Various studies pointed out EP's antiinflammatory and antioxidant effect, which is a more stable and lipophilic derivative of pyruvate. In the cytosol, EP is cleaved into ethanol and pyruvate via intracellular esterase $^{13}$. Hence, ethyl pyruvate is purposed to mimic the pluripotent pharmacologic effects of pyruvate, including down-regulation of the secretion of pro-inflammatory cytokines, the assistance of cellular ATP synthesis, and inhibition of apoptosis ${ }^{14,15}$. For example, ethyl pyruvate is an effective scavenger of hydrogen peroxide and other ROS ${ }^{16,17}$. Importantly, ethyl pyruvate represses many neurotoxic and proinflammatory cytokines like TNF-a, COX-2, IL$1 b$, and IL-616,18. Due to these effects, EP was found useful in various central nervous system diseases like; cerebral ischemia ${ }^{19}$, multiple sclerosis $^{20}$, spinal cord injury ${ }^{15}$, and Parkinson's disease ${ }^{21}$. In an experimental chronic cerebral hypoperfusion model, EP was stated to improve memory, reduce lipid peroxidation, and increase antioxidant capacity ${ }^{19}$. Wang and his colleagues reported EP to reverse behavioral changes in a chronic unpredictable mild stress model ${ }^{22}$.

In this study, an FST, an OF test, and a PA test were used to measure the behavioral changes. Porsolt's forced swimming test is the most preferred test to measure depression and antidepressant therapy in animal models. In this test, immobility and reduction in escape 
response is considered as behavioral despair ${ }^{10}$. The open-field test is broadly used to assess qualitative and quantitative ratios of rodents' locomotion ${ }^{23}$. The PA test is studied to assess the amygdala and hippocampus-dependent contextual fear conditioning ${ }^{24}$. This test is a generally used test to assess emotional memory performance in rodents ${ }^{25}$.

In the present study, the IM group's increased immobility in the FST was reversed to normal values with EP therapy. This reduction was found comparable to the antidepressant-like effects of a classical antidepressant, fluoxetine. In the OF test, the reduced motor functions and entrance to the center area in the IM group were reversed in the IM+F group. In the IM+EP group, a similar recovery was expected, but instead, total distance moved, and the time spent in the center was reduced increased. The reduction in both measures can be linked to the reductive effect of EP in willingness to explore. In the PA test acquisition trial, the IM group's stepthrough latencies were higher increased, and in the retention trial, the IM+EP group's latencies were higher increased compared with the CONT group. These behavioral results indicate that EP can heal behavioral despair but also reduce the willingness to explore.

In the biochemical tests in the obtained brain tissues, a significant recovery was observed with EP applications in GPx and SOD levels, which were observed to reduce in the IM group. The neurotrophic factors, BDNF and NGF, increased with EP therapy, but only BDNF level increment was statistically significant. SOD and GPx are two crucial antioxidant enzymes that are known as first-line defense antioxidants. SOD is the most potent antioxidant enzyme in the cell, and it catalyzes superoxide radicals to hydrogen peroxide and molecular oxygen. GPx can be found in mitochondria and sometimes in the cytosol, and it breaks up H2O2. Various studies have reported increments in the antioxidant enzyme systems with antioxidant therapy ${ }^{26}$. Studies reported that EP produces ROS scavenging activity by rapidly and nonenzymatically reacting with hydrogen peroxide, similar to alpha-keto acids ${ }^{27}$. A study conducted with EP in a chronic cerebral hypoperfusion model reported reductions in oxidative damage and neuroinflammation similar to the present study ${ }^{28}$.

BDNF and NGF are two essential neurotrophic factors that are found in the central nervous system. BDNF is synthesized in the neuron body or neuroglia and transferred to the secretive terminal area, and is known to have essential roles in neuronal growth, development, and synaptic plasticity. Besides, NGF is stated to be related to neuronal survival and learning 29 . In the past few decades, BDNF is declared to have indispensable roles in the antidepressant-like effects of drugs. An increment of BDNF in cortical and hippocampal areas is stated to produce antidepressant effects similar to selective serotonin reuptake inhibitors ${ }^{30}$. The literature data states a correlation with EP and neurotrophic factors, but these studies' results differ. There is undoubtedly a need for more profound researches on the effects of EP in neurotrophic factors. In the states of increased oxidative damage, EP's antioxidant effects may increase neurotrophic factors, while in the states of increased inflammation, antiinflammatory effects of EP may reduce BDNF and NGF levels.

In this study, EP administration reduced depression symptoms in the stress-induced groups in the FST and increased antioxidant enzyme levels, which were reduced in the stress group. Similarly, GPx, SOD, and BDNF levels in the brain were increased with EP therapy. The increment in BDNF levels appears to be associated with EP's antidepressant-like effects in the behavioral tests. 


\section{CONCLUSION}

This study's results have shown the beneficial effects of ethyl pyruvate against immobilization induced stress by antioxidant activity. The study will help scientists reveal the essential areas of stress, behavioral alterations, and antioxidant agents' role in coping with stressrelated illnesses.

As a result, EP is seen to increase neurotrophic factor levels in an experimental stress model via acting as an antioxidant and reverse the depression-like symptoms by acting as a successful antidepressant agent.

Ethics Committee Approval: This study's procedures complied ethically with the local Ethics Committee approval (DUHADEK, Approval date: 30.05.2017, Number: 2017-06) and following The European Community Council Directive 86.

Financial Disclosure: Dicle University financially supported this study (TIP-17-018).

Declaration of Conflicting Interests: There is no conflict of interest

\section{REFERENCES}

1. Terzi F, Türkoğlu HD, Bölen F, et al. Residents' perception of cultural activities as quality of life in Istanbul. Soc Indic Res. 2015; 122: 211-34.

2. Deveci SE, Çalmaz A, Açık Y. The relationship between anxiety level and health, social and demographical factors in the students of a newly established university in Eastern Anatolia. Dicle Med J. 2012; 39: 189-96.

3. Berk A, Yılmaz İ, Abacıoğlu N, et al. Antidepressant effect of Gentiana olivieri Griseb. in male rats exposed to chronic mild stress. Libyan J Med. 2020; 15: 1725991.

4. Li J, Hou L, Wang C, et al. Short term intrarectal administration of sodium propionate induces antidepressant-like effects in rats exposed to chronic unpredictable mild stress. Front Psychiatry. 2018; 9: 454.
5. Korkmaz H, Önal D, Alışık M, et al. The impact of oxytocin on thiol/disulphide and malonyldialdehyde/glutathione homeostasis in stressed rats. Biol Chem. 2020; 401: 1283-92.

6. Biala G, Pekala K, Boguszewska-Czubara A, et al. Behavioral and biochemical interaction between nicotine and chronic unpredictable mild stress in mice. Mol Neurobiol. 2017; 54: 904-21.

7. Rong Z, Pan R, Chang L, et al. Combination treatment with ethyl pyruvate and IGF-I exerts neuroprotective effects against brain injury in a rat model of neonatal hypoxic-ischemic encephalopathy. Int J Mol Med. 2015; 36: 195-203.

8. Shim HS, Lee WG, Kim YA, et. al. Anti-apoptotic and myocardial protective effects of ethyl pyruvate after regional ischaemia/reperfusion myocardial damage in an in vivo rat model. Singapore Med J. 2017; 58: 557.

9. Prut L, Belzung C. The open field as a paradigm to measure the effects of drugs on anxiety-like behaviors: a review. Eur J Pharmacol. 2003; 463: 333.

10. Porsolt RD, Bertin A, Jalfre MJAIP. Behavioral despair in mice: a primary screening test for antidepressants. Arch Int Pharmacodyn Ther. 1977; 229: 327.

11. Akar F, Mutlu O, Celikyurt IK, et. al. Effects of 7$\mathrm{NI}$ and ODQ on memory in the passive avoidance, novel object recognition, and social transmission of food preference tests in mice. Med Sci Monit Basic Res. 2014; 20: 27.

12. Kumar A, Kaur G, Rinwa P. Buspirone along with melatonin attenuates oxidative damage and anxietylike behavior in a mouse model of immobilization stress. Chin J Nat Med. 2014; 12: 582-9.

13. Dong N, Xu X, Xue C, et. al. Ethyl pyruvate inhibits LPS induced IPEC-J2 inflammation and apoptosis through p38 and ERK1/2 pathways. Cell Cycle. 2019; 18: 2614-28.

14. Su X, Wang $\mathrm{H}$, Zhu L, et al. Ethyl pyruvate ameliorates intracerebral hemorrhage-induced brain injury through anti-cell death and antiinflammatory mechanisms. Neuroscience. 2013; 24: 99-108. 
15. Yuan Y, Su Z, Pu Y, et. al. Ethyl pyruvate promotes spinal cord repair by ameliorating the glial microenvironment. Br J Pharmacol. 2012; 166: 74963.

16. Zhou S, Sakamoto K. Pyruvic acid/ethyl pyruvate inhibits melanogenesis in B16F10 melanoma cells through PI3K/AKT, GSK3 $\beta$, and ROS-ERK signaling pathways. Genes Cells. 2019; 24: 60-9.

17. Yang R, Zhu S, Tonnessen TI. Ethyl pyruvate is a novel anti-inflammatory agent to treat multiple inflammatory organ injuries. J Inflamm Res. 2016; 13: $1-11$.

18. Jang M, Lee MJ, Cho IH. Ethyl pyruvate ameliorates 3-nitropropionic acid-induced striatal toxicity through anti-neuronal cell death and antiinflammatory mechanisms. Brain Behav Immun. 2014; 38: 151-65.

19. Lin $\mathrm{Y}$, Chen L, Li W, et al. Role of high mobility group box 1 in myocardial ischemia/reperfusion injury and the effect of ethyl pyruvate. Exp Ther Med. 2015; 9: 1537-41.

20. Djedović N, Stanisavljevic S, Jevtić B, et al. Antiencephalitogenic effects of ethyl pyruvate are reflected in the central nervous system and the gut. Biomed Pharmacother. 2017; 96: 78-85.

21. Maria Miranda Santos C. New agents promote neuroprotection in Parkinson's disease models. CNS Neurol Disord Drug Targets. 2012; 11: 410-8.

22. Wang B, Lian YJ, Su WJ, et. al. HMGB1 mediates depressive behavior induced by chronic stress through activating the kynurenine pathway. Brain Behav Immun. 2018; 72: 51-60.
23. Kulesskaya N, Voikar V. Assessment of mouse anxiety-like behavior in the light-dark box and open-field arena: role of equipment and procedure. Physiol Behav. 2014; 133: 30-8.

24. Gumuslu E, Mutlu O, Celikyurt IK, et al. Exenatide enhances cognitive performance and upregulates neurotrophic factor gene expression levels in diabetic mice. Fundam Clin Pharmacol. 2016; 30: 376-384.

25. Karimi SA, Salehi I, Shykhi T, et al. Effects of exposure to extremely low-frequency electromagnetic fields on spatial and passive avoidance learning and memory, anxiety-like behavior and oxidative stress in male rats. Behav Brain Res. 2019; 359: 630-8.

26. Demiroz S, Ur K, Ulucan A, et. al. Neuroprotective Effects of Lacosamide in Experimental. Turk Neurosurg. 2019; 29: 718-23.

27. Turkmen S, Mentese A, Karaguzel E, et. al. A comparison of the effects of $\mathrm{N}$-acetylcysteine and ethyl pyruvate on experimental testicular ischemiareperfusion injury. Fertil Steril. 2012; 98: 626-31.

28. Ozacmak HS, Ozacmak VH, Turan I. Ethyl pyruvate prevents from chronic cerebral hypoperfusion via preserving cognitive function and decreasing oxidative stress, caspase 3 activation and IL-1 $\beta$ level. Bratisl Lek Listy. 2018; 119: 469-75.

29. Björkholm C, Monteggia LM. BDNF-a key transducer of antidepressant effects. Neuropharmacology. 2016; 102: 72-9.

30. Castrén E, Kojima M. Brain-derived neurotrophic factor in mood disorders and antidepressant treatments. Neurobiol Dis. 2017; 97: 119-126. 